\title{
ENVIRONMENT CRIMINAL LAW IN TODAY EUROPEAN UNION
}

\section{Flămînzeanu}

\section{Ion Flămînzeanu}

Faculty of Law, "Spiru Haret" University, Romania

Institute for Legal Research “Andrei Rădulescu”, Romanian Academy, Bucharest, Romania

*Correspondence: Ion Flămînzeanu, 12 Emil Rahoviță Blvd., bl. R3, ap. 25, sector 4, Bucharest, Romania

E-mail: ionflaminzeanu@yahoo.com

\begin{abstract}
Environment crime is among the European Union's central concerns. The Tampere European Council of 15 and 16 October 1999 at which a first work program for the European Union action in the field of Justice and Home Affairs was adopted asked that efforts be made to adopt common definitions of offences and penalties focusing on a number of especially important sectors, amongst them environment crime. But despite this agreement about the importance of joint the European Union action, environmental criminal law has become the centre of a serious institutional fight between the European Commission, supported by the European Parliament on the one hand and the Council, supported by the great majority of the European Union member states on the other hand. At stake is nothing less than the distribution of powers between the first and the third pillars, and therefore also between the Commission and the European Union's member states. The effect of this fight is currently a legal vacuum on general environmental criminal law that was closed with the Directive 2008/99/CE, taking into consideration the cross-border dimension of environmental crime and the existing significant differences in the national legislation of the European Union member states.
\end{abstract}

Key word : Tampere European Council, common definition of offences, third pillars, enviromental crime.

\section{Introduction}

In February 2000, Denmark presented an initiative for a Framework Decision on Environmental Crime. Same country has made a proposal for a Directive on the Protection of the Environment through Criminal Law. Both proposals, defined offences as infringements of secondary environmental legislation or implementing national legislation of and participation in such activities were also considered an offence ${ }^{l}$.

On sanction, the proposals obliged European Union states to provide for natural persons for criminal penalties, involving in serious cases deprivation of liberty. ${ }^{2}$ The Directive proposal went through the first reading of the European Parliament, after which an amended proposal was adopted. But Council never took up the proposal for discussion, only adopting the Danish Framework Decision proposal in $2003^{3}$.

1.The Framework Decision 2003/80/JHA, so adopting, on the protection of the environment through criminal law was build substantively on the structure of the Council of Europe Convention on the Protection of the Environment through Criminal Law. ${ }^{4}$ In the Decision, the offences are defined including the requirement of unlawful behaviour, i.e.

\footnotetext{
${ }^{1}$ The Tampere European Council of 15 and 16 October 1999;

${ }^{2}$ The Directive 2008/99/CE;

${ }^{3}$ The Framework, Decision 2003/80/JHA;

${ }^{4}$ Jean Pradel, Droit pénal général, Paris 1990.
} 
"infringing a law, an administrative regulation or a provision of Community law aiming at the protection of the environment, with an exception of one autonomus offence in Article 2(a).

The European Union states had to ensure that penalties include at least in serious cases, deprivation of liberty which can give rise to extradition, which means generally more than one year of imprisonment, such in Article 5. Article 6 of the Framework Decision defined the grounds on which legal persons must be held responsible for conduct committed for their benefit by persons having a leading position within their structure or when such a person is liable for lack of supervision or control. Sanctions for legal persons should include criminal or non-criminal fines and may include other sanctions such as exclusion from entitlement to public benefits, a judicial winding-up order etc.

The Framework Decision 2003/80/JHA obliged European Union states to establish jurisdiction when the offence was entirely or partly committed in their territory or on board of a ship or on aircraft registered in it or flying its flag and provided for optional jurisdiction grounds, such in Article 8. Additional rules ${ }^{5}$ on extradition and prosecution in particular on offences committed by own nationals outside the territory of a European Union state, had lost their relevance with the introduction of the European Arrest Warrant. ${ }^{6}$

2. When the Framework Decision was adopted in the Council, the Commission always upheld the view that this was not the appropriate legal instrument for provisions on environmental crime. In this situation, environmental criminal law has become the centre of a serious institutional fight between the European Commission and the Council about the possibility to include criminal law related provisions in first pillar instruments. So, briefly after the adoption, in april 2003 the Commission sought annulment of the Framework Decision before the European Court of Justice for wrong legal bases. The Commission was supported by the European Parliament, the Council by eleven European Union states. The Court annulled the Framework Decision and held that its Articles 1-7 could have been properly adopted on the bases of Article 175 TEC so that its adoption under the third pillar provisions infringed upon Article 47 of Treaty on the European Union. ${ }^{7}$

The essential statement was paragraph 48 of the judgment, where the Court said: "However, the last-mentioned finding (according to which generally criminal law is a matter of the European Union Treaty) does not prevent the Community legislature, when the application of effective, proportionate and dissuasive criminal penalties by the competent national authorities is an essential measure for combating serious environmental offences, from taking measures which relate to the criminal law of the European Union states ${ }^{8}$ which it considers necessary in order to ensure that the rules which it lays down on environmental protection are fully effective..."

3. This statement involved significant changes for legislation. ${ }^{9}$ Once the Commission presented the proposal for a new directive on environmental criminal law, to replace the annulled Framework Decision, this directive was adopted by the European Parliament and the Council of the European Union, having regard to the Treaty establishing the European Community and in particular Article 175(1) thereof to the proposal from the Commission, to the opinion of the European Economic and Social Committee, after consulting the Committee of the Regions and in accordance with the procedure laid down in Article 251 of the Treaty.

This Directive (2008/99/CE) on the protection Issue Based of the environment through criminal law was adopted according to Article 174(2) of the Treaty. So, Community policy on the environment must aim at a high level of protection, the Community been concerned at the rise in environmental offences and at their affects, which are increasingly extending beyond

\footnotetext{
${ }^{5}$ P. Salnoge, Droit pénal général, Press Universitaire, 1994.

${ }^{6}$ C. Soyer, Droit pénal et Procedure pénale, Librarie Générale de droit et de jurisprudence, Paris, 1994.

${ }^{7}$ International Review of Penal Law, 2007, Preparatory Colloquium, La Coruna (Spain), 2007, National reports - CD Rom annexes.

${ }^{8}$ Codice penale e leggi complementari, "Giuridiche Simone” Publishing House, 2000.

${ }^{9}$ Le nouveau Code pénal introduit et commenté par Henri Leclerc, Edition du Seuil, 1994.
} 
the borders of the states in which the offences are committed. Such offences pose a threat to the environment and therefore call for an appropriate response.

Experience has shown that the existing systems of penalties have not been sufficient to achieve complete compliance with the laws for the protection of the environment. Such compliance can and should be strengthened by the availability of criminal penalties which demonstrate a social disapproval of a qualitatively different nature compared to administrative penalties or a compensation mechanism under civil law.

Common rules on criminal offences make it possible to use effective methods of investigation and assistance within and between European Union states ${ }^{10}$.

In order to achieve effective protection of the environment, there is particular need for more dissuasive penalties for environmentally harmful activities, typically cause or are likely to cause substantial damage to the air, including the stratosphere, to soil, water, animals or plants, including to the conservation of species.

Failure to comply with a legal duty to act can have the same effect as active behaviour and should therefore also be subject to corresponding penalties ${ }^{11}$.

Therefore, such conduct may be considered a criminal offence throughout the Community of the European Union when committed intentionally or with serious negligence. In the Article 3 of the Directive 2008/99/CE, the European Union states must ensure that a series of fact constitutes a criminal offence when unlawful and committed intentionally or with at least serious negligence, such as the discharge, emission or introduction of a quantity of materials or ionising radiation into air, soil or water which causes or is likely to cause death or serious injury to any person or substantial damage to the quality of air, the quality of soil or water, or to animals or plants.

Another conduct constitutes a criminal offence in the collection, transport, recovery or disposal of waste, including the supervision of such operations and the after-care of disposal sites, and including actions taken as a dealer or a broker-waste management - which causes or is likely to cause death or serious injury to any person or substantial damage to the quality of air, the quality of soil, the quality of water, or to animals or plants. ${ }^{12}$

The fight against maritime pollution through criminal law in the background of the disaster of the tanker "Prestige" off the coast of Galicia in November 2002 highlighted the urgent need for joint European Union action against ship-source pollution. The abovementioned Framework Decision on environmental criminal law that was to be adopted approximately at the same time did not address specifically this issue. Political statements of the European Council were unanimous in calling for the rapid adoption of an European Union legislative framework. In addition to proposals for technical regulations, the Commission presented therefore in spring 2003 two proposals on offences and sanctions, one for a Directive based on Article 80 TEC, the rules on the common transport policy and one for a Framework Decision based on Articles 31 and 34 TEU, which form a unity. The discussions for both instruments were difficult. The Framework Decision 2005/667/JHA "to strengthen the criminal-law framework for the enforcement of the law against ship-source pollution" was finally adopted in July 2005, the Directive 2005/35/EC "on ship-source pollution and on the introduction of penalties for infringements" in September 2005. Two instruments were considered necessary due to the above-mentioned institutional conflict whether criminal law provisions were acceptable in a first pillar instrument. The Commission had initially included most of the criminal law related provisions in its proposal for a directive, however, the Council decided to transfer the majority into the Framework Decision.

The Directive 2008/99/CE on the protection of the environment through criminal law, of the European Parliament and of the Council, having regard to the proposal from the Commission stipulate that is an offence, the shipment of waste, where this activity falls within

\footnotetext{
${ }^{10}$ Strafgesctzbüch, 33 Aufflage, 1999, Beck Texte in Deutscher Taschenbuch Verlag.

${ }^{11}$ Model Penal Code and Commentaires, Part I, Philadelphia, P.A. 1985, The American Law Institute.

${ }^{12}$ Mihaela Agheniței, Constancies of Penal Law General Part, "Universul Juridic" Publishing House, 2010.
} 
the scope of Article 2(35) of Regulation (EC) No.1013/2006 of the European Parliament and of the Council of 14 June 2006 on shipments of waste (6) and is undertaken in a nonnegligible quantity, whether executed in a simple shipment or in several shipments which appear to be linked.

Another criminal offences such are in the Article 3 of the Directive 2008/99/CE refer to the operations of a plant in which a dangerous activity is carried out or in which dangerous substances or preparations are stored or used and which outside the plant, causes or is likely to cause death or serious injury to any person or substantial damage to the quality of air, soil, water or to animals or plants. With the same result are charging the production, processing, handling, use, holding, storage, transport, import, export or disposal of nuclear materials or other hazardous radioactive substances, the killing, destruction, possession or taking of specimens of protected wild fauna or flora species, except for cases where the conduct concerns a negligible quantity of such specimens and has a negligible impact on the conservation status of the species, and trading in specimens of protected wild fauna or flora species or parts or derivatives thereof with the same exceptions.

\section{Conclusions}

Offences are also any conduct which causes the significant deterioration of a habitat within a protected site and the production, importation, exportation, placing on the market or use of ozone depleting substances.

All the European Union states shall ensure (Article 4) that inciting, aiding and abetting the intentional conduct referred to the offences above-mentioned are punishable as a criminal offence, by effective and proportionate, dissuasive penalties for any legal person who don't respect the stipulations of this Directive.

\section{Bibliography}

Mihaela Agheniței, Constancies of Penal Law General Part, "Universul Juridic" Publishing House, 2010.

The Directive 2008/99/CE;

International Review of Penal Law, 2007, Preparatory Colloquium, La Coruña (Spain), 2007, National reports - CD Rom annexes;

The Framework Decision 2003/80/JHA;

Codice penale e leggi complementari, "Giuridiche Simone" Publishing House, 2000;

The Tampere European Council of 15 and 16 October 1999;

Strafgesctzbüch, 33 Aufflage 1999, Beck Texte in Deutscher Taschenbuch Verlag;

P. Salnoge, Droit pénal général, Press Universitaire, 1994;

C. Soyer, Droit pénal et Procedure pénale, Librarie Générale de droit et de jurisprudence, Paris, 1994;

Jean Pradel, Droit pénal général, Paris, 1990; 1994;

Le nouveau Code pénal introduit et commenté par Henri Leclerc, Editions du Seuil,

Model Penal Code and Commentaires, Part I, Philadelphia, P.A. 1985, The American Law Institute. 